\title{
O UNIVERSO PRETO E BRANCO DE EDGAR DEGAS: INVESTIGAÇÃO SOBRE PROCESSO CRIATIVO E REPRESENTAÇÃO DE SUAS FOTOGRAFIAS E MONOTIPIAS
}

\author{
Bárbara Thieme Garcia Tahira*, Filipe Mattos de Salles
}

\section{Resumo}

Esta pesquisa pretende estabelecer relações acerca das obras fotográficas e monotípicas de Edgar Degas. Artista com um espírito avant-garde, Degas explorou os mais diversos meios visuais expressivos, sem maiores preocupações com convenções e críticas. Independente do meio plástico, o rigor técnico e a vivacidade de um olhar à frente de seu tempo levaram o artista a desbravar novas possibilidades no espaço da arte. Através do recorte temático sobre sua a produção artística fotográfica e de monotipias, ambos meios recorrentemente subestimados em sua produção, pretendemos estabelecer relações através de pesquisas bibliográficas e empíricas que superem as semelhanças estéticas e que permitiam não só adentrar seu processo criativo, quanto traçar um panorama mais abrangente de seu contexto e consequentes influências dentro e fora de sua obra.

\section{Palavras-chave: Edgar Degas. Monotipia. Fotografia.}

\section{Introdução}

Figura controversa de um século de diversas revoluções artísticas, Edgar Degas era visto por muitos de seus contemporâneos como o detentor de uma personalidade tempestuosa. "Ele era contudo grande polemista e argumentador terrível, particularmente excitável sobre assuntos de política e desenho." (VALÉRY, 2012, p. 19). Essas características foram notáveis em seus trabalhos, sua inquietação moldou seu rigor técnico e permitiu que explorasse novas mídias com esse mesmo afinco. Nunca estava satisfeito, não se contentava o que Ihe era fácil, o labor era para ele uma diversão que poderia nunca se dar por terminado. (VÁLERY, 2012, p.86). "Assim como com as monotipias, a fotografia foi uma ideia que o consumiu, e ele trabalhou apaixonadamente com isso por um tempo [...]" (BELL, 1999, p.130). Por meio da investigação bibliográfica, pesquisa exploratória e experimentação das técnicas por ele usadas, pretendemos compreender seu processo criativo e, consequentemente, buscamos esclarecer as possíveis relações entre ambas mídias em sua produção tão marcante em seus anos finais

\section{Resultados e Discussão}

O final do século XIX foi sem dúvidas decisivo e notável no que concerne às mudanças nas formas de representação do mundo. $\mathrm{O}$ advento fotográfico aturdiu toda uma sociedade de artistas que, até então, eram detentores dos meios mais precisos de se representar a realidade tal como acreditava-se que ela seria. Dentro desses admiradores encontrava-se Degas. O que poderia parecer como uma grande contradição de postura (ou até mesmo incoerência) tendo em vista sua tendência ao clássico, na verdade condiz com a forma que tantos autores dizem a respeito de seu espírito avant-garde, em se apropriar dos meios colocando toda sua maestria em busca de novas formas de olhar. Uma reflexão de Rubens Fernandes Jr. reforça, "A fotografia não acabou com a arte de nenhum grande gênio, pois estes souberam vê-la como aliada, ou, na pior das hipóteses, como uma possibilidade visual que poderia apontar para novos processos de criação." (2002, p.34, apud SALLES, p.114). Portanto, quando as considerações sobre possíveis conexões entre os acasos preto e branco nesses diferentes meios empenhados por Degas começaram a mover a pesquisa, tornou-se inevitável o esbarrar em análises no campo das representações das imagens. Fayga Ostrower quando desenvolve a ideia de que na arte as formas expressivas são sempre formas de estilo, linguagem, condensação de experiências, formas poéticas, leva-nos a enxergar a criação artística para além de sua produção final. Vê-se, desse modo, uma necessidade não só estilística nas novas apropriações de Degas, mas também existencial, "todo ato de criação é um ato de compreensão que redimensiona o universo humano." (OSTROWER, 2013, p. 219)

\section{Conclusões}

É possível dizer que apesar de não haver registros e estudos específicos sobre uma verdadeira ligação e influência entre as técnicas, ficou evidente após o estudo bibliográfico de análises feitas por diversos autores de suas obras que, ainda que, aparentemente tênue, a existência de correlação entre as duas mídias a partir dessa conjectura seria factível. Quando Francis Cachin escreve sobre suas monotipias, estabelece também uma conexão, mesmo que no campo estilístico, com a fotografia que surgiu e se popularizou contemporaneamente a produção dos anos finais de Degas, "A monotipia é um documento sobre o mundo como ele é, ao invés do que uma visão do mundo a qual é ditada por alguns princípios artísticos - e a observação de Degas é genuinamente fotográfica" (1974, p.80). Já Crimp, em seu texto Positive/Negative: A Note on Degas's Photographs, quando aborda as impressões fotográficas do artista e sua variedade aponta o fato de que " [...] demonstram o mais alto nível de experimentação de Degas com seus negativos, elaborando e estendendo os tipos de experimentos que havia realizado em preto e branco nas monotipias há dez anos."(1978, p.98). Assim, as escolhas das mídias se deram não por mero acaso ou pura experimentação sem fundamentos, mas como expressão de uma filosofia visual constante na obra do artista, a eterna impressão de si mesmo e de seus anseios perante as representações de arte.

\section{Agradecimentos}

\section{Agradeço ao SAE/UNICAMP pela bolsa concedida}

ADHEMAR, Jean. Degas: the complete etchings, lithographs and monotypes. Coautoria de Françoise Cachin. London: Thames and Hudson, 1974.

BELL, J. Degas' other passion. The World \& I, Washington, v. 14, n. 1, p. 128-133,1999.

CRIMP, Douglas. Positive/Negative: A Note on Degas's Photographs. Cambridge, MA; London : The MIT Press, v. 5, p. 89-100, outubro 1978.

OSTROWER, Fayga. Acasos e criação artística. 1 ed. Campinas, SP:Editora da Unicamp, 2013.

SALLES, Filipe. A ideia-imagem: forma e representação na fotografia moderna.Curitiba, PR: Appris, 2016

VALÉRY, Paul. Degas dança desenho. 1 ed. São Paulo, SP: CosacNaify, 2012 . 